\title{
POLIMER-KERÁMIA-FÉM KOMPOZIT RENDSZEREK TANULMÁNYOZÁSA
}

\section{STUDY OF POLYMER-CERAMIC-METAL COMPOSITE SYSTEMS}

\author{
Bődi Szabolcs \\ Kecskeméti Föiskola, Gépipari és Automatizálási Müszaki Főiskolai Kar (GAMF), \\ Természet- és Müszaki Alaptudományi Tanszék, H-6000 Magyarország, Izsáki út \\ 10.; Telefon: +36-76-516338, bodi.szabolcs@gamf.kefo.hu
}

\begin{abstract}
The aim of our paper is to present the foreign research achievements of polymer-ceramic-metal composite systems. The first part of our paper shows the application fields of metal foams. The second part presents the fiber-reinforced composites. In part three we present the mechanical behaviour of glass fibre reinforced polypropylene skinned (Plytron) sandwich beams and the mechanical behaviour of sandwich beams produced from Alporas aluminium alloy foam. Then we present the application of aluminium foam hybrid sandwich sructures in lightening the battery housings for electric vehicles. Finally, I sum up the conclusions regarding the studied papers.
\end{abstract}

Keywords: metal foam, polymer composite, glass fibre reinforcement, polypropylene skin, aluminium alloy foam, battery house.

\section{Összefoglalás}

Cikkünk célja a polimer-kerámia-fém kompozit rendszer külföldi kutatási eredményeinek illetve alkalmazásának az ismertetése. Az első részben bemutatjuk a fémhabok felhasználásnak területeit. A második részben ismertetjük a szálerősítésű polimer kompozitokat. A harmadik részben ismertetjük az üvegszállal erősített polipropilén héjú (Plytron) és az Alporas alumínium ötvözethabból gyártott szendvics rudak mechanikai viselkedését. Ezután bemutatjuk az alumíniumhab hibrid szendvicsszerkezetek alkalmazását az elektromos járművek akkumlátorházának könnyítésénél.

Kulcsszavak: fémhab, polimer kompozit, üvegszál erösités, polipropilén héj, alumínium ötvözethab, akkumlátorház.

\section{Bevezetés}

Napjaink fejlesztőmérnökeinek egyik célkitüzése a tervezett gépek tömegének csökkentése, ami által jelentős energiatakarékosságra tehetünk szert. Egyre több fém alkatrészt helyettesítünk fémhabbal, különböző szálerösítésü polimer kompozittal, melyek a kisebb tömegükön túl adott esetben jobb tulajdonságokkal is rendelkeznek, így az elvárt funkciót teljes mértékben el tudják látni [1].

Idáig Magyarországon a polimerkerámia-fém kompozit rendszer tanulmányozása új területnek számít.

Cikkünk célja ezen kompozit rendszer külföldi kutatási eredményeinek, illetve alkalmazásának az ismertetése. 


\section{Fémhabok felhasználása}

A fémhabok egyedülálló mechanikai, elektromos, termikus és akusztikus tulajdonságokkal rendelkező kis sürüségủ anyagok. Nagy fajlagos szilárdságuk és jó hangszigetelő képességük révén elő-szeretettel használják az építőiparban, kis hővezető képességük és kiváló hődiffuzitásuk előnyös az elektronikai ipar számára, míg jó energiaelnyelő képességük forradalmasította a csomagolástechnikát, a hadiipart (pl. golyóálló mellények bélése), a jármüipart, mely utóbbinál szendvics-paneleket készítenek belölük [2].

\section{A szálerősített polimer kompozitok ismertetése}

Ma már sok esetben szálerősítésű polimer kompozitból készül az autók karosszériája, alkatrészeinek nagy része is. Kiváló adhéziós kapcsolat van ezen kompozit két fő alkotóeleme, a szívós mátrix és a nagy szilárdságú erősítőanyag között. A szálak feladata a terhelések felvétele, míg a mátrixé a szálak terhelésközvetítése, befoglalása. A polimer kompozitok előnyei a tervezhető mechanikai tulajdonságok, a kis sürüség, az elektromos és mágneses szigetelőképesség, nagy szilárdság, korrózióállóság [3].

Az alábbiakban ismertetjük az üvegszálas, szénszálas, illetve az üveg/szénszálas hibrid erősítés jellemzőit.

A szervetlen, amorf szerkezetü üveg a szilikátok csoportjába tartozik. A müanyagok erősítésére leginkább a viszonylag olcsó E-üveget használják a müszaki üvegszálak közül, ami jó elektromos szigetelőképességgel bír. Az epoxigyanta mátrixú kompozitok vizsgálata során kimutatták, hogy a mechanikai tulajdonságok folyamatosan romlanak a páratartalom növekedésével. Az üvegszálas kompozitok ismétlődő húzó-igénybevétel szembeni viselkedésének tanulmányozása során a próbatestek nyúlása a vizsgálati idővel együtt növekedett [4].
A szénszálakat a szerves szénvegyületekből pirolitikus úton állítják elő. A nagy rugalmassági modulus és rendkívül nagy grafitszilárdság miatt használják. A mindennapi élet egyre több területén alkalmazzák, pl. az autóiparban, építőiparban, sportszergyártásnál. A szénszövettel erösített epoxigyanta mátrixú kompozitokra gyakorolt hőmérséklet és nedvesség együttes hatásának vizsgálatából kiderült, hogy romlott a szál-mátrix adhézió, de javult a kompozitok ütésállósága [4].

A szénszál üvegszállal való hibridizációjával a kompozitok ütésállósága javítható és nagymértékben csökkenthető az áruk. Epoxigyanta mátrixú üveg/szénszálas hibridkompozitok ütésállóságának vizsgálatából kiderült, hogy nagyobb energia értékek mellett a szálszakadás volt jellemző, míg kisebb energiánál a tönkremenetel módja a delamináció és a mátrixdeformáció. Különböző száltartalmú rövid üveg- és szénszállal erősített polipropilén mátrixú hibridkompozitok vizsgálata során kiderült, hogy a szénszál-tartalom növekedésével csökken a szakadási nyúlás és növekszik a rugalmassági modulus és a húzószilárdság [4].

\section{Polimer-kerámia-fém kompozit rendszerek tanulmányozása}

S. Mcknown és R.A.W. Mines tanulmányukban az üvegszállal erősített polipropilén héjú (Plytron) és az Alporas alumínium ötvözethabból gyártott szendvics rudak mechanikai viselkedését vizsgálták.

Az Alporas hab vizsgálata során a cellafalak feszítettsége, a cellaélek hajlása befolyásolják a zárt cellájú fémhab deformációjának mechanizmusát. Nyomás hatására szerkezeti károsodások jönnek létre az egyes tartományokban, valamint a cellaélek elhajlanak. Az Alporas magú habminta nyomástesztje során ugyanazt az 1,6 MPa folyáshatárt kapták az azonos sürüségű 20 illetve $40 \mathrm{~mm}$ vastagságú minták esetében, 
amiből következik, hogy a 6 közepes cellaátmérőnél (kb. $20 \mathrm{~mm}$ vastagság) kisebb vastagságú Alporas réteg esetén jelentkezik a habméret-hatás.

Hárompont-hajlítású kvázisztatikus és kissebességü ütközéses teszttel tanulmányozták a Plytron héjú és Alporas magú szendvicsrúd viselkedését, amint az 1. ábrán látható. Megfigyelték, hogy mind az indenter (benyomótest), mind a támasztékok körül plasztikus bemélyedések jöttek létre. A központi terhelési tartományban a mag összezúzódása, a felső héj kompresszív, majd degresszív károsodása figyelhető meg. A nyírófeszültség okozta a mag károsodását, az indenter alatti nyomás pedig a felső héj károsodásának a kiváltó oka.

Mivel a 10 mm magvastagságú rúd vastagsága azonos nagyságrendü a cellamérettel, ezért katasztrofális károsodás lépett fel ezeknél a rudaknál. Ezzel ellentétben ugyanazokat a magkárosodásokat okozta az indenter 10-30 mm-es elmozdulása a 20 mm magvastagságú felső héj károsodása esetén. Ebből következik, hogy magkárosodást okoz az alumíniumhabban az anyagszerkezet gyenge pontjaiban (egybeolvadt cellák tartományai, a cellaméretek nagy variációja, a szennyeződések koncentrálódása, a szerkezeti hibák) [5].

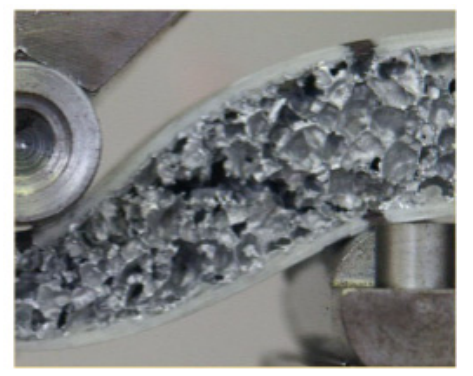

1. ábra. Rögzített rúd kísérlet során bekövetkezett károsodása [5]

Joachim Baumeister és társai vizsgálták az elektromos jármüvek akkumlátor házának könnyítési lehetőségét, melyet alumíni- umhab hibrid szendvicsszerkezetek alkalmazásával kívánt elérni. A tisztán elektromos meghajtású járművek akkumlátortelepe a lehető legkönnyebb kell legyen, mivel hosszú út megtételét kell, hogy lehetővé tegye, ezért az akkumlátorház gyártásánál alumínium hibrid magokat közrefogó alumínium oldallapokat alkalmaztak.

A lehető legnagyobb kell, hogy legyen az akkutelep energiasürüsége a megfelelö vezetési táv eléréséhez. Az energiasürüséget az akkutelep súlyának csökkentésével lehet elérni. Ezért úgy építették be a gépkocsi padlózatába az akkutelepet, hogy az akkumlátorház teteje a padlószerkezet legyen, majd alumíniumhab szendvics anyagból gyártották az akkuház alját.

$\mathrm{Az}$ ún. APM (Advanced Pore Morphology-Fejlett Pórusos Szerkezet) technológiával granulátum formában gyártották elő az alumíniumhabot, majd hőkezeléssel aktivált ragasztóval vonták be a granulátumokat annak érdekében, hogy nagyobb szerkezetekké kössék össze. Azért, hogy kombinálják a polimerhab könnyü felhasználhatóságával az alumíniumhab jó energiaelnyelő képességét, alumíniumpolimer hibridet hoztak létre az alumíniumhab granulátumok polimerhab mátrixba ágyazásával.

Az alumíniumhab granulátumokat habosító kémiai anyagokat tartalmazó ragasztóval vonták be, majd beöntötték az előállítandó szendvics szerkezet két lemeze közé. Ezt követően a ragasztó megolvad, felhabzik a hőkezelés hatására és összeragasztja egymással az alumínium gömböket és az oldallapokat (2. ábra).
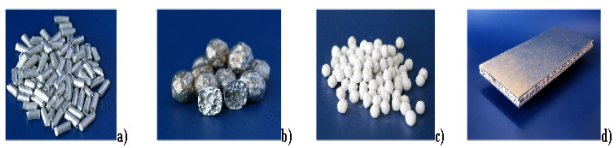

2. ábra. A hibrid hab technológia folyamat lépései: a) elöregyártott, vágott aluminium b) APM habositott granulátumok c) APM habzó polimerrel bevonva, d) hibrid habszendvics [6] 
Szervo-hidraulikus tesztgépet használtak a dinamikus nyomástesztekhez. Nagy sebességü videokamerával határozták meg a megnyúlást, piezoelektromos cellával mérték az erőt. A kompresszió görbékből több jellemzőt meg tudtak határozni: a fajlagos térfogati energiaelnyelést, a nyomó szilárdságot, a tangens modulust, a feszültségplató átlagértékét.

A kísérletek alapján megállapították, hogy nő a hibrid anyag folyáshatára az alumínium mennyiség növekedésével, ennek megfelelően az APM sürüsége növekedésével növekszik az elnyelt fajlagos energia és a feszültségplató. A feszültségplató arányosan növekszik a burkolat vastagságának növekedésével.

Ütközéskor nagyobb védelem érhető el az alumíniumhab szendvics jó energiaelnyelö képességének és vastagságának köszönhetöen [6].

\section{Következtetések}

Egyre több helyen kombinálják a szálerösített polimer kompozitokat fémhabbal azért, hogy ki tudják használni mindkettő előnyös tulajdonságait. Ennek érdekében különböző kísérleteket végeznek a fémhabbal kombinált kompozit rendszerek tulajdonságainak meghatározására.

Ebben a cikkben az üvegszállal erösített polipropilén héjú (Plytron) és az Alporas alumínium ötvözethabból gyártott szendvics rudak mechanikai viselkedését ismertettük. 6 közepes cellaátmérőnél (kb. 20 mm vastagság) kisebb vastagságú Alporas réteg esetén jelentkezik a habméret-hatás. A hárompont-hajlítású kvázisztatikus és kissebességü ütközéses tesztekből kiderül, hogy a mag összezúzódása, a felső héj kompresszív, majd degresszív károsodása figyelhető meg. A nyírófeszültség okozta a mag károsodását, az indenter alatti nyomás pedig a felső héj károsodásának a kiváltó oka. Magkárosodást okoz az alumíniumhabban az anyagszerkezet gyenge pontjaiban [5].

Bemutattuk az elektromos jármüvek akkumlátor házának könnyítési lehetőségét, melyet a szerző alumíniumhab hibrid szendvicsszerkezetek alkalmazásával kívánt elérni. Megállapították, hogy nő a hibrid anyag folyáshatára az alumínium mennyiség növekedésével, ennek megfelelöen az APM sürüsége növekedésével növekszik az elnyelt fajlagos energia és a feszültségplató. A feszültségplató arányosan növekszik a burkolat vastagságának növekedésével. Ütközéskor nagyobb védelem érhető el az alumíniumhab szendvics jó energiaelnyelő képességének és vastagságának köszönhetően. [6]

\section{Szakirodalmi hivatkozások}

[1] Orbulov, I., és mások: Fémhabok és kompozitok elöállitása infiltrálásos eljárással. Bányászati és kohászati lapok, Budapest, 140. évfolyam, 5. szám, 2007, 4146.

[2] Kenesei, P.; Kádár, Cs.; Rajkovits, Zs.; Lendvai, J.: Fémhabok elöállitásának módszerei, Anyagok Világa, Budapest, 2001,

[3] Czigány, T.: Hibrid szálerösitésü polimer kompozitok. Anyagvizsgálók Lapja, Budapest, 2004, 59-62.

[4] Tamás, P.: Bazaltszállal erösitett polimer mátrixú kompozitok fejlesztése. PhD értekezés, Budapesti Műszaki és Gazdaságtudományi Egyetem Gépészmérnöki Kar, Budapest, 2013, 15-31.

[5] McKown, S.; Mines, R.A.W.: Impact behaviourof metal foam cored sandwich beams. Department of Engineering, University of Liverpool, Liverpool.

[6]Baumeister, J. és mások: Applications of aluminium hybrid foam sandwiches in battery housings for electric vehicles. Elsevier Ltd., 2014,317-321. 